\title{
Teacher Skills Through the Development of Design and Develop Learning Program Taedes 401 (gov.au) for Building Core Skill and Employability Skills for Vocational High School
}

\author{
Asep Yudi Permana ${ }^{1}$, Dini Injani Aprilia ${ }^{1}$ and Nuruh Qolbu Irbani Teniola ${ }^{1}$ \\ ${ }^{I}$ Universitas Pendidikan Indonesia, Jln. Dr. Setiabudhi no. 207 Bandung, Indonesia \\ yudi.permana@upi.edu,diniinjani@upi.edu,nurulqolbi@upi.edu
}

Keywords: Practical skills, Supporting competencies, Practical Equipment, Effectiveness, Facilitators.

\begin{abstract}
The demand for policy reform in the midst of increasingly dynamic currents and waves of modernization is urgently needed in the development of the industrial revolution 4.0 based on this cyber-physical system. The product of the industrial revolution is closely related to the practical equipment used in Vocational High Schools (SMK) as supporting student competencies. The aim of vocational education is to provide practical skills in mastering the use of practical equipment as supporting competencies because vocational secondary education is actually an escalation to channel human resources ready to enter the workforce. Thus, updating learning programs in vocational education has become a necessity. True teachers, as facilitators in learning in vocational schools, are expected to provide understanding and work skills. The learning process does not only fill the material alone but is able to provide skills and work skills in accordance with what is needed in the business world and the world of work. Therefore, teachers must be able to conceptualize, design, develop, and study learning programs to meet identified needs for a group of students. Model TADES401 (gov.au) as one program in designing and developing learning programs. This model discusses the skills and knowledge needed to identify the parameters of a learning program, determine its design, describe content, and review its effectiveness. There are 4 (four) units of skills, namely: (1) define the essential outcomes; (2) work within the VET policy framework; (3) develop program content; (4) design the structure of the learning program. Of the four skill units, they are derived into 15 (fifteen) skills of a teacher that must be done in developing this learning model. In the process of implementing the TAEDES401 model, teachers are required to be able to complete their tasks to (1) designing, developing and reviewing learning programs within the vocational education and training (VET) context; (2) preparing and developing a minimum of two learning programs: and (3) that contain differentiated learning program designs to reflect particular needs, contexts and timelines. Through the design and development of the TADES401 learning program, it will be a variant and not monotonous, the teacher's skills in managing the class will have a positive impact on core skills and employability skills (CSaES).
\end{abstract}

\section{INTRODUCTION}

Education (Andriani, 2010) as one of the important factors in creating a country's civilization, because the progress of the country is determined by the quality of education. In its development, education always changes. This is in line with the changing times marked by the rapid progress of information technology. Education is the most effective way to overcome the constraints of the limited capacity of the people who are ready to participate in the development process. To support this, there is a need for new breakthroughs and innovations in implementing education policies to create quality education, thus impacting quality human resources. Human parameters can be said to be quality when individuals are able to solve problems in life independently, accountability, credibility, and ethics in the social.

The era of industrial revolution 4.0 marked the development of digital technology, the development of social societies, economic development and other developments will not be rejected and inhibited. The development of extraordinary science and technology 
in all fields, information from various corners of the world can be accessed instantly and quickly by anyone and from anywhere, interpersonal communication can be done easily and cheaply. These changes are increasingly felt, including in the world of education.

Teachers as the spearhead and important elements in an education system will be very influential in the learning process of students. Teachers face challenges that are far greater than the previous era because each student has a diverse learning style (Rahman, 2014). Nowadays teachers face clients that are far more diverse, more complex subject matter, standard learning processes and demands for achieving higher thinking skills. For this reason, teachers who are able to compete are no longer relying on intelligence but rather on creativity and intelligence acting (hard skills-soft skills).

\section{LITERATURE}

\subsection{Learning Program}

Learning is a term taken from the word "instruction" translation. According to Sadiman, the words learning and teaching can be distinguished based on their understanding. Sadiman further stated that teaching is only in the context of teacher-student's informal classes, while learning does not only exist in the context of teacher-students in formal classes but also includes teaching and learning activities through planned efforts in manipulating resources learn.

Learning is one form of the program because good learning requires careful planning. In addition, the implementation of learning involves various people, both teachers and students, having a connection between one learning activity and another learning activity, namely to achieve competency in the field of study which ultimately supports the achievement of graduate competencies, and takes place in an institution or agency.

According to McDavid and Hawthorn (2006) defines that programs as meaning relationships are designed and applied purposively. A program can be understood as a group of activities intended to reach one or several related targets (Karimnia, 2015).

The learning program is a teaching plan as a teacher's guide in carrying out teaching. In order for learning to work effectively and efficiently, it is necessary to make a learning program. The role of the teacher is not only limited to teaching (the delivery of science), but also as a guide, developer, and manager of learning activities that can facilitate student learning activities in achieving their intended goals.

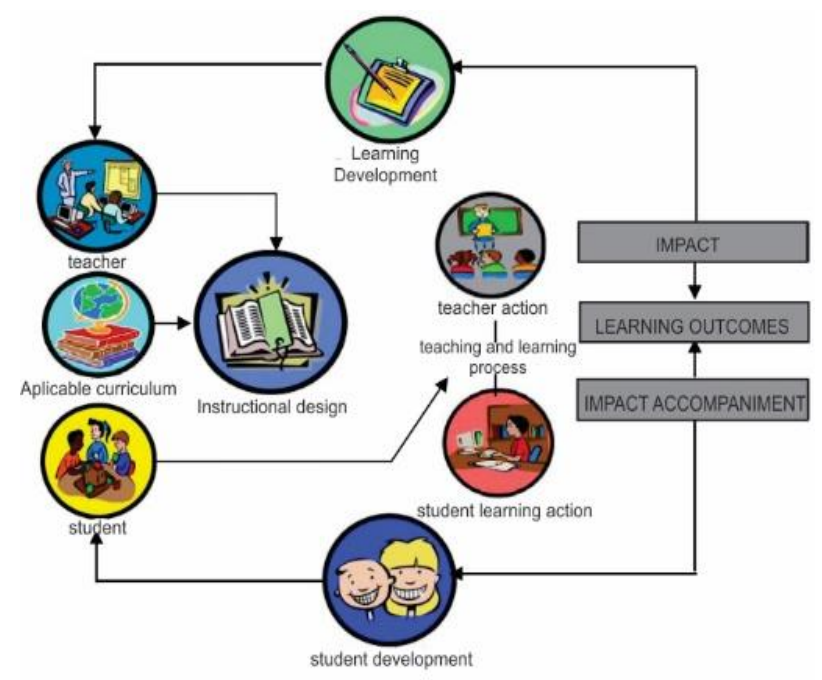

Figure 1. Learning Activities

Source: (Riyana, 2016)

Learning programs have an important role to play in creating effective learning. In the learning program, a teacher describes the goals to be achieved, the subject matter that will be taught, the steps that will be taken to achieve that goal, and how to measure the achievement of the planned goals. According to Arends (2012), effective learning can be seen in students' acquisition or mastery of teaching material, and mastery of good and complete teaching material. Popham and Baker (2005) explain that the success of the learning process depends on the selection and use of strategies and the teaching methods used in accordance with the learning objectives. Learning methods and strategies must be well planned and prepared.

The formulation of learning programs is not just the origin or origin but must be good and right. Good in terms of plans for learning programs that can facilitate and facilitate teachers in carrying out their duties, not otherwise complicate and confuse teachers in learning. While true means the formulation of learning programs must be carried out in accordance with the elements that should be contained in a learning program.

Learning programs are learning and assessment strategies that are used to convey and assess unit competencies. The scope of the learning program is the learning outcomes or learning objectives that come from the standards of competence and outline, the sequence, the learning structure and the delivery and assessment methods to be used. 
The learning program is the design or planning of one unit or the continuity of activities in the learning process, which has a purpose and involves a group of people (teachers and students) to achieve the set goals. The intended purpose is the achievement of learning outcomes derived from competency standards.

Learning as a system has four components, namely (a) Context; (b) input; (c) process; and (d) products. As shown in the picture 2 .

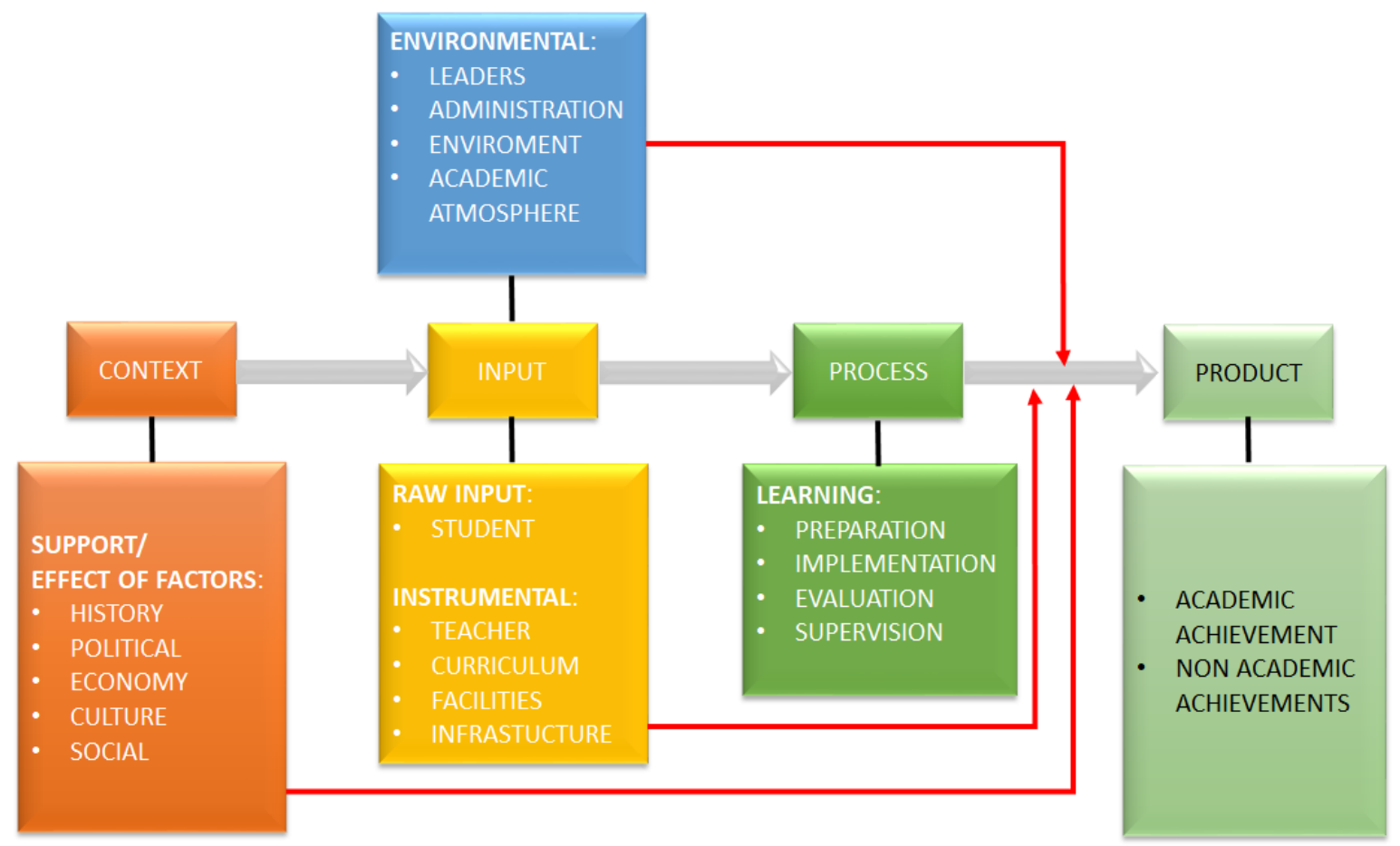

Figure 2. Learning System

Source: Nur'aini (2000)

\subsection{Skill Learning Model Era of Industrial Revolution 4.0}

Today's learning model has evolved from a traditional approach that emphasizes memorization into a model of inquiry-based learning that is meaningful, has true value and relevance, to develop the ability of critical thinking and the independence students need (Barron and Darling-Hammond, 2008). Where each student must explore skills through increased learning to be able to overcome global challenges, such as critical thinking skills, the ability to communicate effectively, innovate and solve problems through negotiation and collaboration (Scott, 2015).

Learning in the industrial revolution era 4.0 develops competencies and skills that are complex and integrated. There are 6 (six) elements of competence and skills that are expected to develop in this learning process, including personalization, collaboration, communication, informal learning, productivity, and content creation.
These six elements are also key to today's overall vision of learning. The world of work also requires personal skills (having initiative, tenacity, responsibility, risk-taking, and creativity), social skills (working in teams, networking, empathy and compassion), and learning skills (managing, organizing, metacognitive skills, and not easily discouraged or change perceptions / points of view in the face of failure).

Saavedra and Opfer (2012) suggest 9 (nine) principles for teaching skills, namely (1) making learning relevant to 'big picture'; (2) teaching with discipline; (3) developing lower and higher thinking skills to encourage understanding in different contexts; (4) encourage the transfer of learning; (5) teach how to 'learn to learn' or metacognition; (6) correct misunderstanding directly; (7) promoting teamwork; (8) utilizing technology to support learning; and (9) increasing student creativity (Zubaidah, 2016).

Learning design will play a central role in the success of learning today. Creativity and ability of 
teachers in designing interesting learning activities are very important. Mcloughlin and Lee (2008) stated that effective and innovative learning practices are in accordance with the subjects, and the emphasis is on digital competencies that focus on individual creativity and performance; strategies for metalearning, including designed learning; inductive and creative reasoning models, and problem solving; compilation of collaborative learning content and knowledge formation; horizontal learning (peer-topeer), and other things.

The ideal learning model for meeting educational goals needs to involve $4 \mathrm{C}$ principles, namely critical thinking, communication, collaboration and creativity.

\subsection{Skills of the Era of Industrial Revolution 4.0}

The era of industrial revolution 4.0 requires skills that must be mastered by someone, so it is expected that education can prepare students to master various skills in order to become a successful person in life (Atmojo, Sajidan, Sunarno, and Ashadi, 2019). Important skills in the era of industrial revolution 4.0 are still relevant to the four pillars of life, namely learning to know, learning to do, learning to be and learning to live together. In addition, there are special skills that are empowered in learning activities, namely critical thinking skills, problem-solving, metacognition, communication skills, collaborating, innovation and creation, information literacy, and various other skills.

To achieve the skills needed in the era of industrial revolution 4.0 needs to be done by updating the quality of learning, helping students develop participation, adjusting personalization of learning, emphasizing project/problem based learning, encouraging collaboration and communication, increasing student involvement and motivation (Atmojo et al., 2019), cultivating creativity and innovation in learning, using the right learning tools, designing learning activities that are relevant to the real world, empowering metacognition, and developing student-centered learning (Atmojo et al., 2019).

According to Wagner (2010), identifying the competencies and skills needed by students in facing life and the world of work is emphasized in 7 (seven) skills, namely (1) the ability to think critically and problem-solving, (2) collaboration and leadership, (3) agility and adaptability, (4) initiative and entrepreneurial spirit, (5) capable of communicating effectively both orally and in writing, (6) being able to access and analyze information, and (7) having curiosity and imagination. Whereas based on the USbased Apollo Education Group identified 10 (ten) abilities needed by students to work, namely: critical thinking skills, communication, leadership, collaboration, adaptability, productivity and accountability, innovation, global citizenship, ability and spirit of entrepreneurship, and the ability to access, analyze and synthesize information (Barry, 2012; Zubaidah, 2016)

\subsection{Core Skills and Employability Skills (CSaES) Framework}

Skill is one factor in the effort to achieve success in achieving organizational goals. The purpose of work skills is to be able to facilitate a job in the completion of each job effectively and efficiently without any difficulties until it will produce a good performance.

Various terminologies are currently used within the international research community to refer to the category of employability skills. The term of employability skills has gained prominence of late because of the changing world of work. Employability is used interchangeably with other terms such as generic skills, transferable skills, nontechnical skills, core skills, key skills, essential skills, and 21 st-century skills. These skills were seen to have relevance to both entry-level and established employees. Employability skills framework has been developed in many countries. This framework describing the need for employability skills, and outlining some existing definitions (Suarta, Pranadi, Suwintana, and Hariyanti, 2017).

Australian Department of Education, Science, and Training (DEST) and Australian National Training Authority (ANTA) commissioned a project that gathered the views of the industry on the critical generic skills required in Australian workplaces. The report from the Australian Chamber of Commerce and Industry (ACCI) and the Business Council of Australia (BCA), defines employability skills are skills required not only to gain employment but also to progress within an enterprise so as to achieve one's potential and contribute successfully to enterprise strategic directions (Scarnati, 2001; DEST Department of Education, 2002; Suarta et al., 2017; Australian Government, 2019b). The Employability Skills Framework, outlined in Employability skills for the future, provides the starting point for any discussion of employability skills in higher education in Australia (Sander and Grip, 2003). The report identified the personal attributes required for today's employees and eight skill groups to describe and define employability skills. The eight skill groupings 
are (1) communication skills, (2) teamwork skills, (3) problem-solving skills, (4) initiative and enterprise skills, (5) planning and organizing skills, (6) selfmanagement skills, (7) learning skills, and (8) technology skills. Personal attributes are terms used to describe a set of non-skill-based behaviors and attitudes that employers felt were as important as the employability skills and other technical or jobspecific skills. The personal attributes included loyalty, commitment, honesty and integrity, enthusiasm, reliability, personal presentation, commonsense, positive self-esteem, sense of humor, balanced attitude to work and home life, ability to deal with pressure, motivation, and adaptability (Treat, 2010; Scott, 2015).
The Learning and Employability Series offers a wide range of perspectives on the employability of graduates. In this documents, employability defined as a set of skills, knowledge and personal attributes that make an individual (graduates) more likely to gain employment and be successful in their chosen occupations, which benefits themselves, the workforce, the community and the economy" (Yorke and Knight, 2006; Suarta et al., 2017). The employability skills framework consists of personal qualities, core skills, and process skills. Each skill groups made up of a number of aspects (Yorke and Knight, 2006) (table 1)

Table 1. List of Employability Aspect

\begin{tabular}{|l|l|l|}
\hline \multicolumn{1}{|c|}{ Personal Qualities } & \multicolumn{1}{c|}{ Core Skills } & \multicolumn{1}{c|}{ Process Skills } \\
\hline Malleable self-theory & Reading effectiveness & Computer literacy \\
\hline Self-awareness & Numeracy & Commercial awareness \\
\hline Self-confidence & Information retrieval & Political sensitivity \\
\hline Independence & Language skills & Ability to work cross-culturally \\
\hline Emotional intelligence & Self-management & Ethical sensitivity \\
\hline Adaptability & Critical analysis & Prioritizing \\
\hline Stress tolerance & Creativity & Planning \\
\hline Initiative & Listening & Applying subject understanding \\
\hline Willingness to learn & Written communication & Acting morally \\
\hline Reflectiveness & Oral presentations & Coping with complexity \\
\hline & Explaining & Problem solving \\
\hline & Global awareness & Inluencing \\
\hline & & Arguing \\
\hline & & Resolving conflict \\
\hline & & Decision-making \\
\hline & & Negotiating \\
\hline & & Teamwork \\
\hline
\end{tabular}

Source: Yorke and Knight (2006)

The core skills developed by the Australian Government can be seen in the picture.

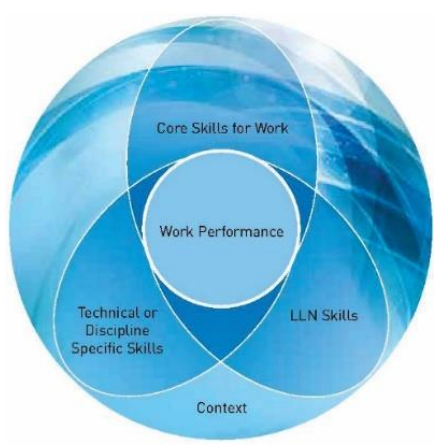

Figure 3. Core skills

Source: Australian Goverment (2013)
Technological developments that are so fast and widespread require labor to change. Skills and knowledge have become the main factors in production, thus direct measurement of competence is a logical step in determining and predicting accurate and reliable workforce success. For that changes in skill requirements are quickly needed by employability skills.

Employability is an individual characteristic that is related to work ability and the desire to remain attractive in the labor market. Employability skills are becoming increasingly important, Sander and Grip (2003) divided them into 3 (three) groups, namely:

a. Fundamental skills, namely skills needed as a basis for further development. These skills consist of communication skills, ability to manage information, and use numbers 
behaviors, have a sense of responsibility, can adapt, desire to continue learning, work carefully, think and solve problems (Amiruddin et al., 2018).

c. Teamwork skills, namely the skills and attributes needed to increase productivity. These skills consist of the ability to cooperate and be able to participate in tasks (Amiruddin et al., 2018).

Heijke et al., (2002) distinguish competency into 3 (three) groups, namely (1) competencies obtained directly in schools, which can be used in the industrial world / world where the business has passed; (2) competencies obtained in schools that facilitate the acquisition of new competencies; and (3) competencies obtained in the context of their work. Thus, it is hoped that a recurring learning process will occur which is more frequent. In this learning process, there will be a connection between the ability of the old facilitator skills with new employability skills. In other words, it will improve the mastery of one's employability skills, which ultimately someone is increasingly trusted to do work with more difficult levels.

Thus, it is hoped that a recurring learning process will occur which is more frequent. In this learning process, there will be a connection between the ability of the old facilitator skills with new employability skills. In other words, it will improve the mastery of one's employability skills, which ultimately someone is increasingly trusted to do work with more difficult levels.

\section{DESIGN AND DEVELOP LEARNING PROGRAM} namely:

a. Fundamental skills, namely skills needed as a basis for further development. These skills consist of communication skills, the ability to manage information, and use numbers (Amiruddin et al., 2018).

b. Personal management skills, namely personal skills, attitude and behaviors that encourage a person's potential to grow. These skills consist of the ability to show positive attitudes and

Tabel 2. Elemen and Performance Criteria

\begin{tabular}{|c|c|}
\hline $\begin{array}{c}\text { ELEMENT } \\
\text { Elements describe the essential } \\
\text { outcomes. }\end{array}$ & $\begin{array}{c}\text { PERFORMANCE CRITERIA } \\
\text { Performance criteria describe the performance needed to demonstrate } \\
\text { achievement of the element. }\end{array}$ \\
\hline $\begin{array}{l}\text { 1. Define the parameters of the } \\
\text { learning program }\end{array}$ & $\begin{array}{c}1.1 \text { Clarify the purpose and type of learning program with key } \\
\text { stakeholders } \\
1.2 \text { Access and confirm the competency standards, and other training } \\
\text { specifications, on which to base the learning program } \\
1.3 \text { Identify language, literacy and numeracy requirements of the } \\
\text { program }\end{array}$ \\
\hline
\end{tabular}


Tabel 2. Elemen and Performance Criteria

\begin{tabular}{|c|c|}
\hline ELEMENT & PERFORMANCE CRITERIA \\
\hline & 1.4 Identify and consider characteristics of the target learner group \\
\hline $\begin{array}{l}\text { 2. Work within the VET policy } \\
\text { framework }\end{array}$ & $\begin{array}{l}\text { 2.1 Access relevant vocational education and training (VET) policies } \\
\text { and frameworks, and apply to work practices } \\
\text { 2.2 Identify changes to training packages and accredited courses, and } \\
\text { apply these to program development } \\
\text { 2.3 Conduct work according to organisational quality assurance } \\
\text { policies and procedures }\end{array}$ \\
\hline 3. Develop program content & $\begin{array}{l}\text { 3.1 Research, develop and document specific subject matter content, } \\
\text { according to agreed design options } \\
\text { 3.2 Evaluate existing learning resources for content relevance and } \\
\text { quality } \\
\text { 3.3 Specify assessment requirements of the learning program }\end{array}$ \\
\hline $\begin{array}{l}\text { 4. Design the structure of the } \\
\text { learning program }\end{array}$ & $\begin{array}{l}\text { 4.1 Break the learning content into manageable segments, and } \\
\text { document the timeframe for each segment } \\
\text { 4.2 Determine and confirm delivery strategies, required assessment } \\
\text { methods and tools } \\
\text { 4.3 Document the complete learning program in line with } \\
\text { organisational requirements } \\
\text { 4.4 Review the complete program with key stakeholders, and adjust as } \\
\text { required } \\
\text { 4.5 Ensure a safe learning progression by analysing risks in the } \\
\text { learning environment, and including a risk control plan }\end{array}$ \\
\hline
\end{tabular}

Source: (Australian Government 2019; Training.gov.au, 2019)

While the basic skills are assessed based on 7 (seven) main skills, namely (a) reading; (b) writing; (c) oral communication; (d) numeracy; (e) Navigate the world of work; (f) Interact with others; and (g) Get the work done (Training.gov.au, 2019). More complete assessment of basic skills according to TAEDES 401 can be seen in the table 3 .

Tabel 3. Fondation Skills

\begin{tabular}{|c|c|c|}
\hline Skill & $\begin{array}{c}\begin{array}{c}\text { Performance } \\
\text { Criteria }\end{array} \\
\end{array}$ & Description \\
\hline Reading & $\begin{array}{l}1.2,1.3,1.4,2.1 \\
2.2,2.3,3.1,3.2 \\
3.3,4.2,4.4,4.5\end{array}$ & $\begin{array}{l}\text { Interprets specific information and instructions from a range } \\
\text { of sources, to identify relevance to requirements }\end{array}$ \\
\hline Writing & $\begin{array}{l}1.1,3.1,3.3,4.1 \\
4.2,4.3,4.4,4.5\end{array}$ & $\begin{array}{l}\text { Develops documents and content using the required format, } \\
\text { accurate spelling, and grammar and terminology specific to } \\
\text { the purpose and audience }\end{array}$ \\
\hline $\begin{array}{l}\text { Oral } \\
\text { Communication }\end{array}$ & 1.4 & $\begin{array}{l}\text { Uses appropriate language, questioning and listening } \\
\text { techniques to provide and elicit information, confirm } \\
\text { understanding and explore others' views. }\end{array}$ \\
\hline Numeracy & 4.1 & $\begin{array}{l}\text { - Interprets familiar measurements relating to timeframes and } \\
\text { compares against requirements }\end{array}$ \\
\hline $\begin{array}{l}\text { Navigate the } \\
\text { world of work }\end{array}$ & 4.3 & $\begin{array}{l}\text { Follows organisational protocols, policies and procedures } \\
\text { regarding program documentation }\end{array}$ \\
\hline $\begin{array}{l}\text { Interact with } \\
\text { others }\end{array}$ & $1.1,1.2,4.2,4.4$ & $\begin{array}{l}\text { - Recognises the importance of consultation and negotiation } \\
\text { while collaborating to confirm strategy and achieve required } \\
\text { outcomes }\end{array}$ \\
\hline $\begin{array}{l}\text { Get the work } \\
\text { done }\end{array}$ & $\begin{array}{l}1.1-1.4, \quad 2.1-2.3 \\
3.1-3.3,4.1-4.5\end{array}$ & $\begin{array}{l}\text { - Organises and completes work according to defined } \\
\text { requirements, taking responsibility for decisions and } \\
\text { sequencing tasks to achieve efficient outcomes } \\
\text { Identifies and responds to potential risks, considering options } \\
\text { for different approaches }\end{array}$ \\
\hline
\end{tabular}


Tabel 3. Fondation Skills

\begin{tabular}{|c|c|c|}
\hline Skill & $\begin{array}{c}\text { Performance } \\
\text { Criteria }\end{array}$ & \multicolumn{1}{c|}{ Description } \\
\hline & & $\bullet \quad \begin{array}{l}\text { Uses information and communications technology (ICT) } \\
\text { based tools to conduct research, design work processes, and } \\
\text { to complete work tasks }\end{array}$ \\
\hline
\end{tabular}

Source: (Australian Government, 2019a; Training.gov.au, 2019)

\section{DISCUSSION}

The importance of core skills and employability skills (CSaES) are increasingly emphasized in recent times. Presently, employers want to recruit graduates not only with technical skills (Muhamad, 2012), as represented by the subject and degree class but also with their employability skills. Graduates' attributes are more important than the graduates 'degree subjects (Muhamad, 2012). Based on the results shown in Table 1, communication skills, problemsolving skills, teamwork skills and personal qualities that are the most important skills attributes to enter the workplace in recent time. Here is a summarizes of important facets of employability skill attributes.

a. Communication Skills

Communication is the process that occurs between two or more people in which a message is delivered and received by the other party. Communication happens every day in the workplace, such as managers give direction to workers, co-workers communicate to plan a project and employees communicate information to customers. The ability to communicate is one of the employability skills attributes necessary for a graduate's success in entering the workforce.

Communication skills related to one's ability in the context of speaking, listening, writing and reading. In order to be able to communicate effectively, a graduate or job seeker must mastery in all domains of communication skill.

Communication skills groups consist of a number of facets: (a) listen effectively, (b) communicate accurately and concisely, (c) effective oral communication, (d) communicate pleasantly and professionally, (e) effective written communication, (f) ask good question, and (g) communicate appropriately and professionally using social media (Crawford, Lang, Fink, Dalton, and Fielitz, 2011).

b. Decision-Making and Problem-Solving Skills

A problem is any difference between an actual situation and the desired situation. Problemsolving is the process of identifying a discrepancy between an actual and desired state of affairs and then taking action to resolve the deficiency or take advantage of the opportunity. In contrast, decision-making is a selection process where one of two or more possible solutions are chosen to reach the desired goal (Huitt, 1992). Decisionmaking refers to the choice of the most appropriate solution among possible alternatives. The steps in both problems solving and decision making are quite similar, and both processes have been characterized as complex processes in which an individual identifies and evaluates several alternative courses of action and selects an alternative for the purpose of implementation. In fact, the terms are sometimes used interchangeably.

Problem-solving and decision-making are important skills for business and life. In order to compete, job seekers in the industrial revolution era 4.0 must be able to find logical solutions to the problems and they also must be able to give effective decisions. The skills of decision-making and problem-solving are not only the results of development and socialization but also inevitable processes that go on throughout the life of an individual. Problem-solving skills that contribute to productive outcomes. Good decision-making requires a mixture of skills: creative development and identification of options, clarity of judgment, firmness of decision, and effective implementation. Here are some useful methods for effective decision-making and problemsolving: (1) problem identification, (2) goal selection, (3) generation of alternative solutions, (4) consideration of consequences associated with alternative solutions, (5) approach to decision making, (6) implementation of solutions, and (7) evaluation of solutions (Lohman, 2004). Decision- making and problem-solving skills groups consist of a number of facets: (a) identify and analyze problems, (b) take effective and appropriate section, (c) realize the effect of decisions, (d) creative and innovative solutions, (e) transfer knowledge from one situation to another, (f) engage in life-long learning, and (g) think abstractly about problems (Crawford et al., 2011; Suarta et al., 2017).

c. Teamwork Skills 
accountability to the team, (e) work with multiple approaches, (f) aware and sensitive to diversity, and (g) share ideas to multiple audiences (Crawford et al., 2011; Suarta et al., 2017).

\section{CONCLUSIONS}

The development of the learning program is divided into 3 (three) parts, namely (1) Learning planning: tailored community souvenirs based on a needs-based curriculum; (2) Implementation of learning: which is carried out every time teaching and learning activities; and (3) Evaluation of learning: carried out after completion of teaching and learning activities that are based on ideas, targets, achievements of teaching and learning activities.

Supporting and inhibiting factors in learning are divided into 2 (two), namely (a) internal factors: understanding the concept of learning; and (b) external factors: the teacher when implementing teaching and learning activities.

The employer's demand indicates that occupationspecific skills are no longer sufficient for graduates to meet the needs of today's labour markets. They prefer to hire graduates who can manage change and thrive on it, flexible and adaptable workers who are quick to learn. Increasingly, graduates' attributes are more important than the graduates 'degree subjects. Employability skills are a very important problem in the labour market in the industrial revolution era 4.0.

Graduates are also expected to have a number of personal attributes including self-awareness, selfconfidence, independence, emotional intelligence, flexibility and adaptability, stress tolerance, creativity, and initiative, willingness to learn, reflectiveness, lifelong learning, and professional behaviour.

\section{ACKNOWLEDGMENTS}

The author would like to give some credits to LPPM UPI which has given the opportunity for the researcher to conduct research through its research grant funding of Research Affirmation scheme.

\section{REFERENCES}

Amiruddin, Mappalotteng, A. M., Nurlaela, \& Sunardi. (2018). Employability Skill Development of Mechanical Engineering Students Through Project member, (b) positive and encouraging attitude, (c) punctual and meets deadline, (d) maintains 
Based Learning in Vocational High School in South Sulawesi. Paper presented at $2^{\text {nd }}$ International Conference on Statistic, Mathematics, Teaching, and Research, 1-8.

Andriani, D. E. (2010). Mengembangkan Profesionalitas Guru Abad 21 melalui Program Pembimbingan yang Efektif. Manajemen Pendidikan, 6, 78-92.

Arends, R. I. (2012). Learning ti Teach (Ninth edit). New York: Mc Graw Hill.

Atmojo, I. R. W., Sajidan, S., Sunarno, W., \& Ashadi, A. (2019). The implementation of skill of disruptive innovators to improve creativity through science learning on green biotechnology conceptions. Paper presented at International Conference on Mathematics and Science Education (ICMScE 2018), 1-6.

Australian Goverment. (2013). Core Skills for Work Developmental Framework (CSfW). Australia: Ithaca group.

Australian Government. (2019a). Assessment Requirements for TAEDES401 Design and develop learning programs. Australia: Australian Government.

Australian Government. (2019b). TAEDES401 Design and develop learning programs. Australia: Australian Government.

Barron, B., \& Darling-Hammond, L. (2008). teaching for Meaningful Learning: A Review of Research on Inquiry-Based and Cooperative Learning. San Francisco: John Wiley and Sons Inc.

Barry, M. (2012). What skills will you need to succeed in the future? Phoenix Forward (online). Phoenix: Tempe, AZ, University of Phoenix.

Crawford, P., Lang, S., Fink, W., Dalton, R., \& Fielitz, L. (2011). Comparative Analysis of Soft Skills: What is Importance for New Graduates? Washington DC: Association of Public and Land-grant Universities.

DEST (Department of Education, S. and T. (2002). Employability skills for the future. A Report by the Australian Chamber of Commerce and Industry (ACCI) and the Business Council of Australia (BCA) for the Department of Education, Science and Training. Canberra: Department of Education, Science and Training.

Fisher, S. G., Hunter, T. A., \& Macrosson, W. D. K. (1997). Team or group? Managers' perceptions of the differences. Journal of Managerial Psychology, 12, $232-242$.

Griffin, M., \& Annulis, H. (2013). Employability skills in practice: The case of manufacturing education in Mississippi. International Journal of Training and Development, 17, 221-232.

Heijke, H., Meng, C., \& Ramaekers, G. (2002). An Investigation into The Role of Human Capital Competences and Their pay-off. Maastricht: Research Centre for Education and The Labor Market, Faculty of Economics and Business Administation.

Huitt, W. G. (1992). Problem-solving and decision making: Consideration of individual differences using the Myers-Briggs Type Indicator. Journal of Psychological Type, 24, 33-44.

Karimnia, A. (2015). An Evaluation of Undergraduate
TEFL Program in Iran: A Multi- Case Study. International Journal of Instruction, 8, 83-98.

Kozlowski, S., \& Ilgen, D. R. (2006). Enhancing the Effectiveness of Work Groups and Teams. Psychological Science, 7, 77-124.

Lohman, M. C. (2004). The development of a multirater instrument for assessing employee problem-solving skill. Human Resource Development Quarterly, 15 , 303-321.

McDavid, J. C., \& Hawthorn, L. R. L. (2006). Program evaluation and performance measurement. USA: SAGE Publications.

Mcloughlin, C., \& Lee, M. J. W. (2008). The Three P's of Pedagogy for the Networked Society: Personalization, Participation, and Productivity. International Kournal of Teaching and Learning in Higher Education, 20,1027.

Muhamad, S. (2012). Graduate Employability and Transferable Skills : A Review, 6, 882-885.

Nur'aini, E. (2000). Program Pembelajaran. Retrieved from

https://amaeka.files.wordpress.com/2012/11/programpembelajaran.pdf

Popham, W. J., \& Baker, E. L. (2005). Teknik mengajar secara sistematis. Jakarta: Rineka Cipta.

Rahman. (2014). Keterampilan Guru Abad 21 dalam Variabel Penguasaan Media Audio Visual. Bandung. Retrieved from http://file.upi.edu/Direktori/FPBS/JUR._PEND._BAH ASA DAERAH/195704011984121-

RAHMAN/KETERAMPILAN GURU ABAD 21 DALAM VARIABEL PENGUASAAN MEDIA AUDIO VISUAL.pdf

Riyana, C. (2016). K omponen-komponen Pembelajaran. In Kurikulum Pembelajaran. Bandung: UPI Press.

Saavedra, A. R., \& Opfer, V. D. (2012). Teaching and Learning 21st Century Skills: Lessons from the Learning Sciences. New York: Asia Society.

Sander, \& Grip, D. (2003). Training, task Flexibility and Low-skilled Workers' Employability. Maastricht: Research Centre for Education and The Labour Market, Faculty of Economics and Businness Administrtion. Retrieved from Training, task Flexibility and Lowskilled Workers' Employability

Scarnati, J. T. (2001). On becoming a team player. Team Performance Management. An International Journal, 7 , $5-10$.

Scott, C. L. (2015). The Futures of Learning 3: what kind of pedagogies for the 21st century?. Education, Research and Foresight: Working Papers, 1-21.

Suarta, I. M., Pranadi, F., Suwintana, I. K., \& Hariyanti, N. K. D. (2017). Employability skills required by the $21 \mathrm{st}$ -century workplace: a literature review of labour market demand, (January) https://doi.org/10.2991/ictvt-17.2017.58

Training.gov.au. (2019). Training. Australia: Training.gov.au.

Treat, T. (2010). The Challenge for VET in Developing Skills for Today's Workforce. In International Seminar Vocadtional Education and Training. Yogyakarta: 
Graduate School Yogyakarta State University Indonesia.

Wagner, T. (2010). Overcoming The Global Achievement Gap (online). Cambridge, Mass.: Harvard University. Yorke, M., \& Knight, P. T. (2006). Embedding employability into the curriculum. York. United Kingdom: The Higher Education Academy.

Zubaidah, S. (2016). Keterampilan abad ke-21: keterampilan yang diajarkan melalui pembelajaran. In Seminar Nasional Pendidikan, Tema "Isu-isu Strategis Pembelajaran MIPA Abad 21. Kalimatan Barat: Program Studi Pendidikan Biologi STKIP Persada Khatulistiwa Sintang. 